\title{
Sudut Hijau : Sebagai Rekayasa Sosial Bagi Program Pemberdayaan Kesejahteraan Keluarga
}

\author{
Kartika Nuringsih ${ }^{1 *}$, Nuryasman $\mathrm{MN}^{2}$, Heni Mularsih ${ }^{3}$, Frans ${ }^{4}$ \\ ${ }^{1}$ Fakultas Ekonomi, Universitas Tarumanagara Jakarta \\ ${ }^{2}$ Fakultas Ekonomi, Universitas Tarumanagara Jakarta \\ ${ }^{3}$ Fakultas Psikologi, Universitas Tarumanagara Jakarta \\ ${ }^{4}$ Fakultas Ekonomi, Universitas Tarumanagara Jakarta \\ Author E-mail: kartikan@fe.untar.ac.id
}

\begin{abstract}
A B S T R A K
Kegiatan pengabdian bertujuan membantu Program Pemberdayaan Kesejahteraan Keluarga (PKK) dalam mewujudkan masyarakat produktif yang berorientasi ramah lingkungan. Sesuai dengan masalah mitra maka luaran berupa rekayasa sosial berkebun di RT 02/02 Beji Timur. Metode pelaksanaan melalui bekerjasama \& sosialisasi dengan Ketua Pengerak PKK serta melibatkan 10 ibu rumah tangga (dasawisma) dalam praktek berkebun. Rekayasa berkebun memanfaatkan lahan tidur serta lahan terbatas antara rumah-rumah warga di RT 02/02. Kebun didesain secara vertikal menggunakan pralon atau kerangka baja ringan \& talang plastik. Model memudahkan ibu rumah tangga melakukan aktivitas berkebun serta mudah memindahkan di lahan lain. Manfaat luaran menjembatani kebiasaan berkebun dengan perilaku pro-lingkungan. Diawali dengan pilah sampah kemudian secara kolektif sampah dapur dikomposkan menjadi pupuk. Berbagai jenis sayuran dapat ditanam melalui media kebun vertikal sehingga membantu mewujudkan kemandirian sayuran segar bagi keluarga. Secara spesifik rekayasa berkebun sebagai mekanisme edukasi perilaku pro-lingkungan kepada warga serta penerapan ipteks bagi masyarakat. Secara general rekayasa sosial menginspirasi masyarakat berkebun atau media komunikasi bagi sesama penggiat berkebun. Untuk penerapan secara lebih luas perlu didasari oleh komitmen kuat dari kader serta proses evaluasi sehingga proses perbaikan akan dilakukan sebelum musim tanam berikutnya.
\end{abstract}

Kata Kunci: Rekayasa, Berkebun, PKK, Perilaku, Pro-lingkungan.

\section{A B S T R A C T}

The community empowerment activity aims to help Family Prosperity Empowerment Program (PKK) in creating environmentally oriented productive society. In accordance with partner problems, the output is in the form of gardening engineering in RT 02/02 Beji Timur. The implementation method is through collaboration and outreach with the Chairperson of PKK involving 10 housewives (dasawisma) in gardening practices. Gardening engineering utilizes wastelands and narrow fields between citizen's houses in RT 02/02. The gardens designed vertically using water pipe or mild steel frame and plastic gutter. The model makes it easier for housewives to do gardening activities and move them to another lands. The output benefit is bridging gardening habits with pro-environment behavior. Starts with sorting out the trash and then the kitchen trash composted into fertilizer collectively. Various types of vegetables can be planted through vertical garden so that helps the families with the fresh vegetable 
independence. Specifically gardening engineering is a pro-environment behavior education mechanism and the application of science and technology in the society. Generally, the social engineering inspires gardening community or communication media for fellow gardeners. For wider application, it needs to be based on strong commitment and evaluation process from the cadre so that the repair process will be carried out before the next planting season.

Keywords: Engineer, Gardening, PKK, Behavior, Pro-environment.

Copyright (c) 2019 Authors. This is an open access article distributed under the Creative Commons Attribution License, which permits unrestricted use, distribution, and reproduction in any medium, provided the original work is properly cited.

\section{PENDAHULUAN}

Sebagai upaya mewujudkan kota yang bersih dan hijau maka banyak gerakan yang diinisiasi oleh masyarakat. Salah satu komunitas urban yang tertarik dengan aktivitas berkebun adalah "Depok Berkebun" dimana komunitas ini merupakan afiliasi "Indonesia Berkebun". Kepedulian berkebun bukan sekedar bukan sekedar mengajak masyarakat berkebun tetapi memiliki relevansi dengan Pro-Environmental Behavior (PEB). Pada perilaku ini terbentuk kesadaran untuk meminimalisasi efek negatif terhadap lingkungan/alam (Kollmuss \& Agyeman, 2002). Mekanisme perilaku ini diukur berdasarkan berbagai dimensi diantaranya conservation, environmental citizenship, food (Markle, 2013), shopping behavior (Bamberg \& Rees, 2015) atau recycling \& waste avoidance (Kaiser \& Wilson, 2007). Menurut Hoffmann \& Muttarak salah satu treatment dalam menghadapi perubahan iklim melalui kegiatan berkebun. Perilaku tersebut berdampak positif terhadap kualitas lingkungan sehingga fungsi keluarga (Erhabor \& Oviabon, 2018) memiliki peran penting dalam proses penerapan PEB. Oleh karena itu digagas sudut hijau sebagai rekayasa sosial untuk menghubungkan antara praktek berkebun dengan perilaku pro-lingkungan.

Gagasan dari Indonesia Berkebun diadopsi berbagai kota diantaranya Depok Berkebun serta diterapkan oleh perguruan tinggi salah satunya Universitas Indonesia Berkebun. Antusias terbentuknya kota asri dengan basis ramah lingkungan merupakan harapan masyarakat. Kreativitas berkebun dilakukan melalui lahan pekarangan atau memanfaatkan lahan tidur sebagai kebun bersama. Pada sebagian masyarakat menghadapi keterbatasan lahan atau tidak memiliki ruang terbuka hijau. Melalui kegiatan pengabdian diupayakan terbentuk sudut hijau sebagai sarana berkebun supaya dapat menumbuhkan sikap positif terhadap perilaku pro-lingkungan (Palupi \& Sawitri., 2017).

Dikaji dari aspek psikologi maka gender menjadi pertimbangan dalam implementasi PEB (Blankenberg \& Alhusen, 2018; Gifford \& Nelsson, 2014). Kaum wanita dinilai lebih perhatian terhadap isu-isu lingkungan dibandingkan kaum pria (Longhi, 2013) atau memiliki environmental attitude lebih kuat daripada pria (Zelezny et al., 2000). Walaupun demikian bagi pria yang memiliki pengetahuan tentang perilaku hijau masih bersedia terlibat dalam aktivitas ramah lingkungan. Artinya terdapat perbedaan antara pria dan wanita dalam perilaku pro-lingkungan (Eisler et al., 2003) sehingga atas pertimbangan tersebut khalayak mitra dipilih dari Kelompok Pemberdayaan Kesejahteraan Keluarga. Kelompok ini terdiri dari ibu rumah tangga sehingga diharapkan akan lebih peduli dengan masalah sosial dan lingkungan. Dengan demikian tujuan kegiatan pengabdian untuk menindaklanjuti atau mengembangkan kegiatan sebelumnya yang digagas secara perorangan dan kelompok. Sebagian warga masih belum menyadari efek positif aktivitas berkebun atau tidak peduli dengan pemanfaatan sisa lahan untuk berkebun. Atas dasar situasi tersebut direalisasikan dua sudut hijau sebagai rekayasa sosial bagi Program Pemberdayaan Kesejahteraan Keluarga atau PKK RT 02/02 Beji Timur Depok. 


\section{METODE DAN PELAKSANAAN PKM}

\section{Keterkaitan Aktivitas Berkebun Dengan Pro-} environmental Behavior

Mengacu dengan Blankenberg \& Alhusen (2018) dijabarkan berbagai dimensi pro-environmental behavior yaitu: recycling, conservation of energy, conservation of water, transport, consumptionfood, consumption-products, consumption-reuse, nutrition, political behavior, environmental citizenship behavior, long term PEB decisions, intention willingness to pay. Berdasarkan dimensi tersebut maka aktivitas berkebun selaras dengan empat dimensi yaitu: (1) Recycling: compost garden or kichen waste, buy products with less packaging. (2) Consumption-food: buy locally produced foods, buy organic food, grow your own food, waste less food, buy food at a farmer's market. (3) Consumption-products: buy environmental friendly products. (4) Environmental citizenship behavior : talk to children about how food is grown, educate yourself about the environment. Dengan mempertimbangkan dimensi dan indikator tersebut maka melalui rekayasa berkebun diharapkan mampu menumbuhkan sikap positif terhadap perilaku pro-lingkungan.

\section{Kontribusi Aktivitas Berkebun dalam Sustainable Development Goals (SDGs)}

Meskipun sederhana kegiatan pengabdian memiliki relevansi terhadap SDGs. Sesuai dengan UNDP, praktek berkebun memberi kontribusi terhadap pencapaian SDGs khususnya terkait dengan empat target yaitu: zero hunger, gender equality, climate action, life below water, life on land (http://www.undp.org/content/undp/en/ home/sustainable-development-goals.html). Upaya mengajak ibu rumah tangga dalam aktivitas berkebun dapat membantu merealisasikan perilaku pro-lingkungan pada kehidupan seharihari. Sesuai dengan Gambar 1 apabila keterlibatan dan komitmen berkebun terjalin dalam jangka panjang maka aktivitas ini memberi kontribusi dalam pencapaian tujuan pembangunan berkelanjutan.

Mengacu dengan program tersebut meskipun kecil hasil praktek berkebun dapat bermanfaat untuk mencukupi kebutuhan pangan untuk keluarga sehingga dapat mengatasi masalah kelaparan (zero hunger). Di samping itu adanya partisipasi wanita (ibu rumah tangga) dalam kegiatan ini memiliki peran dalam kesetaraan gender (gender equality). Selanjutnya, dengan adanya sikap positif terhadap masalah lingkungan berarti memiliki kepedulian pada perubahan iklim (climate action), berusaha menjaga ekosistem sungai dan bawah laut (life below water) serta ekosistem darat (life on line). Dengan demikian melalui gerakan berkebun bukan sebatas hobi atau sekedar berorientasi secara ekonomi tetapi memiliki kontribusi terhadap masalah sosial serta mitigasi dampak negatif kondisi lingkungan. Implementasi gerakan berkebun dalam skala besar dan berjangka panjang akan membantu pemerintah dalam merealiasikan SDGs.

\section{Pelaksanaan Kegiatan PKM}

Praktek berkebun baru melibatkan 10 keluarga (dasawisma) tergabung pada PKK di RT 02/02 Kalurahan Beji Timur. Dasawisma merupakan kelompok terdepan dalam kegiatan PKK sehingga luaran ini diharapkan sesuai dengan Misi Gerakan PKK yaitu: Meningkatkan derajad kesehatan keluarga, kelestarian lingkungan hidup serta perencanaan sehat (PKK, 2016). Misi tersebut

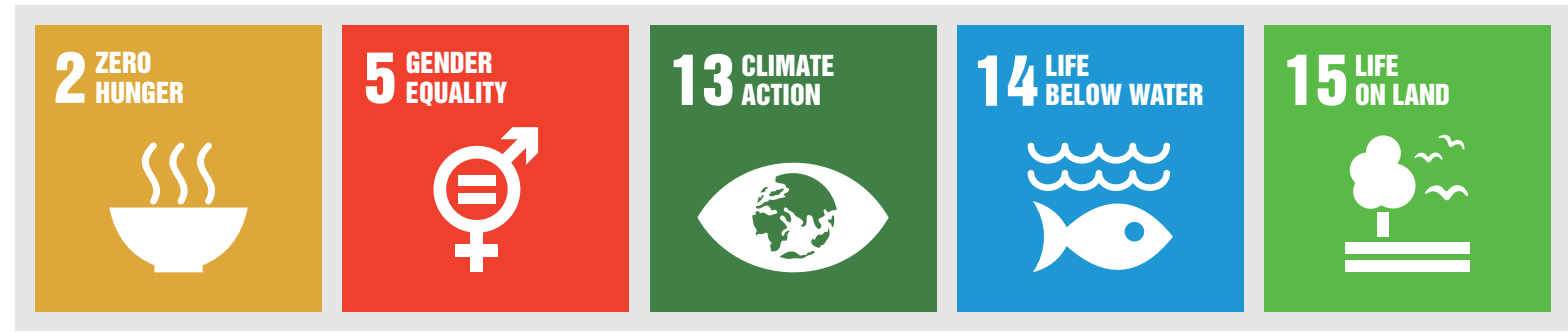

Sumber: http://www.undp.org/content/undp/en/home/sustainable-development-goals.html

Gambar 1. Keterkaitan dengan Program SDGs 
menjadi tanggung jawab Kelompok Kerja (Pokja) III dengan program yaitu: (1) Mengembangkan dan memanfaatkan potensi dan sumberdaya keluarga dalam rangka memenuhi kebutuhan keluarga dan diversifikasi pangan lokal. (2) Pemanfaatan sumberdaya alam melalui teknologi tepat guna dengan memanfaatkan lahan pekarangan (PKK, 2016). Dengan demikian aktivitas berkebun relevan dengan semboyan HATINYA PKK yang bertujuan menciptakan "Halaman, Asri, Teratur, Indah dan Nyaman". Luaran kegiatan berupa sudut hijau atau kebun contoh diharapkan dapat membantu kader dalam merealisasikan misi di atas.

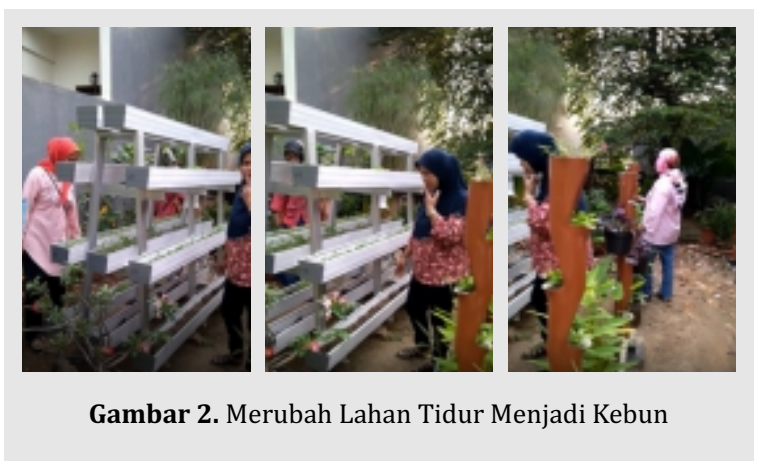

Pada Gambar 2 terlihat kader PKK yaitu: Ibu Nimah, Ibu Ika Kartikawati, Ibu Welasmi, Ibu Atik maupun lainnya sedang mempersiapkan sudut hijau atau kebun contoh PKK RT 02/02. Fokus pertama berkebun adalah memanfaatkan lahan kosong sebagai kebun sayur mayur dan tanaman herbal (Gambar 2) sedangkan fokus kedua untuk memanfaatkan sisa lahan menjadi sudut hijau (Gambar 4). Kriteria pengukuran luaran berupa terjalin kebersamaan dan menumbuhkan minat berkebun bagi ibu rumah tangga. Spesifikasi target luaran yaitu : (1) Sepuluh ibu rumah tangga secara kolektif melakukan aktivitas berkebun. (2) Kebun digunakan untuk menanam sayuran dengan masa tanam pendek serta untuk tanaman herbal. (3) Melakukan pendataan tanaman herbal yang masih digunakan oleh warga dengan target 100 jenis.

Dalam proses mempersiapkan luaran dilakukan diskusi dengan ekspert yang membidangi kegiatan berbasis masyarakat, yaitu: Ibu Intan dari Komunitas Depok Berkebun dan fasilitator dari
Bank Sampah \& Unit Pengolahan Sampah Kota Depok. Berdasarkan saran pihak tersebut disesuaikan dengan kebutuhan PKK sehingga berhasil dibuat luaran berupa kebun contoh atau sudut hijau. Untuk menelaah aspek psikologi melibatkan Dr. Heni Mularsih sedangkan terkait sustainable development melibatkan Dr Nuryasman MN. Koordinasi mitra dilakukan oleh Kartika Nuringsih sedangkan untuk proses pelaksanaan dan administrasi dibantu Frans selaku asmawa Lab. Manajemen Keuangan. Pemilihan model kebun vertikal bertujuan untuk memudahkan ibu rumah tangga melakukan aktivitas penanaman serta penyesuaian dengan kondisi lahan. Dengan model ini aktivitas berkebun terasa ringan serta mudah dipindahkan pada area/lahan lainya.

\section{HASIL DAN PEMBAHASAN}

Kegiatan ini menghasilkan luaran berupa sudut hijau dan kebun contoh sebagai rekayasa sosial untuk mengajak masyarakat melakukan aktivitas berkebun sekaligus mempraktekan perilaku ramah lingkungan. Mekanisme rekayasa berkebun sebagai berikut. Pertama: Sesuai dengan Perda Kota Depok bahwa warga dianjurkan melakukan pilah sampah. Sampah organik diolah menjadi pupuk organik sedangkan sampah plastik didistribusikan kepada bank sampah atau diberikan kepada pemulung. Sampah dapur berupa sisa sayuran, kulit buah, pembungkus tempe, kupasan bawang merah/putih atau sampah hijau lainnya dapat diolah menjadi kompos. Melalui pemisahan tersebut maka volume sampah yang diangkut di tempat pembuangan akhir akan berkurang. Dengan demikian langkah pertama memiliki korelasi terhadap perilaku pro-lingkungan khususnya mengurangi sampah (waste minimization) di RT 02/02.

Kedua: Sampah dapur (organik) dimasukan dalam tabung komposter ditambahkan dengan larutan Em4. Larutan tersebut dapat dibeli pada kios pertanian atau online seharga \pm Rp. 28.000 ,per botol ukuran 1 liter. Takaran disesuaikan dengan aturan penggunaan. RT 02/02 sudah memiliki 6 komposter kapasitas ukuran $20 \mathrm{~kg}$ sehingga secara kolektif sangat mudah bagi 
ibu rumah tangga melakukan aktivitas ini. Dalam 1 komposter menghasilkan 1-2 liter pupuk cair dalam waktu 2 minggu. Jika 5-10 keluarga bersedia menggunakan 1 komposter maka kebiasaan tersebut akan mengurangi volume sampah serta menghasilkan pupuk cair untuk berkebun.

Ketiga: Keterbatasan lahan di RT 02/02 diatasi dengan cara memanfaatkan sisa pekarangan atau lahan tidur. Penggunaan lahan ini tentu saja sudah mendapat ijin dari pemiliknya. Supaya menghemat tempat maka pemilihan model berkebun dibuat secara vertikal. Untuk menghindari lapuk dan memudahkan pemindahan lahan digunakan material dari baja ringan \& talang plastik. Pada area sangat sempit digunakan pot vertikal dari pralon sehingga menghemat lahan dan tidak mengganggu aktivitas warga. Melalui media tersebut ditanam aneka tanaman seperti pada Gambar 3 dan 4. Jenis sayuran dengan masa panen pendek ditanam melalui media vertikal. Diantaranya: kangkung, bayam merah, bayam hijau, sawi, pak-choy, cabe rawit, cabe hijau, tomat, terong, kemangi, kenikir dan parea. Media tanam dan bibit sayuran dapat dibeli melalui kios pertanian sedangkan aktivitas pemupukan selanjutnya dapat menggunakan dari pupuk cair. Karena masih skala kecil maka hasil sudut hijau terbatas atau baru dimanfaatkan oleh keluarga terutama untuk kebutuhan sayur dan bubur balita. Pemanfaatan tanaman herbal ataupun sayuran dilakukan secara barter antara ibu rumah tangga

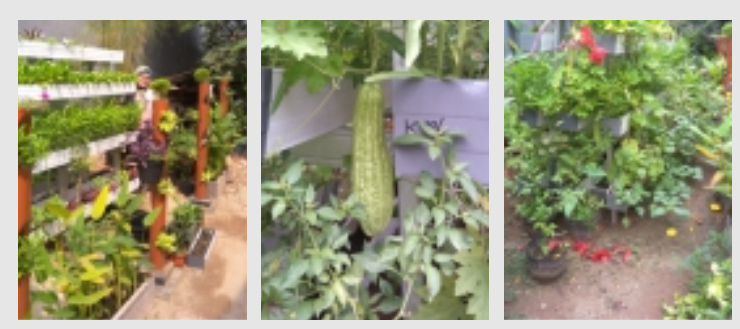

Gambar 3. Sudut Hijau Pertama
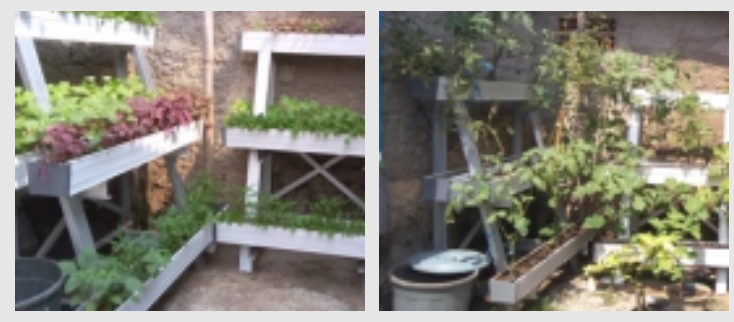

Gambar 4. Sudut Hijau Kedua
Keempat: Mendata tanaman herbal dengan target 100 jenis. Tetapi hasil pendataan baru mencapai 40-an jenis tanaman herbal. Tanaman tersebut adalah: Pohon kelor, kumis kucing, duri seribu, jahe merah, jahe emprit, kencur, puyang, sirih kuning, sirih hijau, sirih kodok, sirih merah, binahong, mustajab, kembang teleng, kapulogo, bawang dayak, oktra, kunyit putih, kunyit kuning, temu lawak, cimplukan, daun afrika, temu kunci, temu ireng, handilem, pohon jarak, delingo, saga, serei merah, serai hijau, pohon katu, pohon garut, ginseng, pandan wangi, sambung nyawa, pohon tin, jeruk purut, jeruk nipis, salam kari, salam biasa, bangle dan mint. Tanaman tersebar pada rumah-rumah warga atau dititipkan di kebun contoh.

Kelima: Pemeliharaan sudut hijau \& kebun diserahkan kelompok demikian juga dengan penanaman ulang dikelola secara kolektif. Sudut hijau s ebagai edukasi bahwa dengan lahan terbatas serta media vertikal dapat dilakukan aktivitas berkebun. Sayuran yang dihasilkan dari sudut hijau juga lebih segar karena baru dipetik dan tidak terlalu tua. Komitmen menjaga dan memelihara kebun sangat penting sehingga tanaman sayuran dapat ditanam dan dipanen setiap 30 hari. Setelah itu dapat ditanam dengan jenis tanaman baru yang disukai oleh warga.

Kelima tahapan sebagai rekayasa sosial untuk membiasakan aktivitas berkebun sekaligus mempraktekan perilaku pro-lingkungan kepada masyarakat. Jika ditelaah melalui Hoffmann \& Muttarak maka sudut hijau dapat menggantikan fungsi ruang terbuka hijau yang makin terbatas. Implementasi rekayasa berkebun diharapkan "Mewujudkan Kemandirian Sayuran Segar Bagi Keluarga". Model tersebut relevan dengan manfaat ekonomi bagi keluarga sehingga memicu sikap positif terhadap perilaku pro-lingkungan diantaranya: recycling, consumption-food, consumption-products, environmental citizenship behavior. Diharapkan semakin tinggi kesadaran terhadap lingkungan berarti semakin banyak kebun atau sudut hijau dibuat oleh warga. Apabila dalam rukun tetangga mampu mempertahankan sudut hijau maka komitmen tersebut akan 
membantu menghijaukan lingkungan perumahan serta mendukung perilaku pro-lingkungan.

Terkait dengan mewujudkan kemandirian sayuran segar bagi keluarga maka mekanisme rekayasa dijelaskan melalui Gambar 5. Skema rekayasa sosial sebagai berikut: (1) Ibu rumah tangga dilibatkan dalam praktek minimalisasi sampah diantaranya memanfaatkan sampah dapur atau organik lainnya. (2) Praktek diarahkan melalui pilah sampah dengan mengkomposkan sampah organik menjadi pupuk. (3). Pupuk dimanfaatkan untuk tanaman sayuran. tanaman herbal atau tanaman hias. (4). Hasil sayuran segar seperti bayam, kangkung, sawi, tomat atau cabe dapat memenuhi kebutuhan sayur-mayur sehingga terbentuk kemandirian bagi ibu rumah tangga dalam menyediakan sayuran segar bagi keluarga. (5) Karena tanpa bahan kimia maka cara berkebun menghasilkan sayuran organik sehingga sesuai dengan dimensi perilaku pro-lingkungan (Bamberg \& Rees, 2015; Lee et al., 2013). Lahan kosong atau sudut-sudut perumahan dapat berdayakan sebagai kebun sayuran secara vertikal atau hijauan lainnya sehingga menciptakan suasana secara lebih asri serta mengantisipasi kekumuhan di lingkungan RT 02/02. Bagi kawasan resapan air, sikap positif berpengaruh terhadap ekosistem darat, sungai dan bawah laut sehingga berkontribusi dalam mitigasi perubahan iklim. Skema di atas merupakan manfaat aktivitas berkebun sehingga untuk memperbesar manfaat harus dilakukan dengan memperluas keterlibatan masyarakat dan dukungan pemerintah maupun pihak terkait lainya.

Dengan demikian untuk memperluas atau mempertahankan luaran terkendala dua faktor yaitu: (1) Faktor alam dimana antara AgustusOktober menghadapi musim kemarau sehingga air sangat terbatas untuk menyiram kebun. Di samping itu berkaitan dengan faktor hama dimana antara Agustus-September hama kutu menyerang pupus daun sawi, di Desember hama belalang menggerek batang/daun dan tanaman cabe terkena kutu putih. (2) Faktor manusia dimana sebagian masyarakat kurang konsisten (kurang teliti) merawat kebun/tanaman. Dengan demikian semangat dan komitmen kader PKK dalam menjalankan Program Pokja III menjadi sangat penting.

\section{KESIMPULAN}

Rekayasa sosial melalui berkebun sudah direalisasikan dalam kegiatan pengabdian masyarakat bersama PKK RT 02/02 Beji Timur Depok. Luaran ini sebagai media untuk

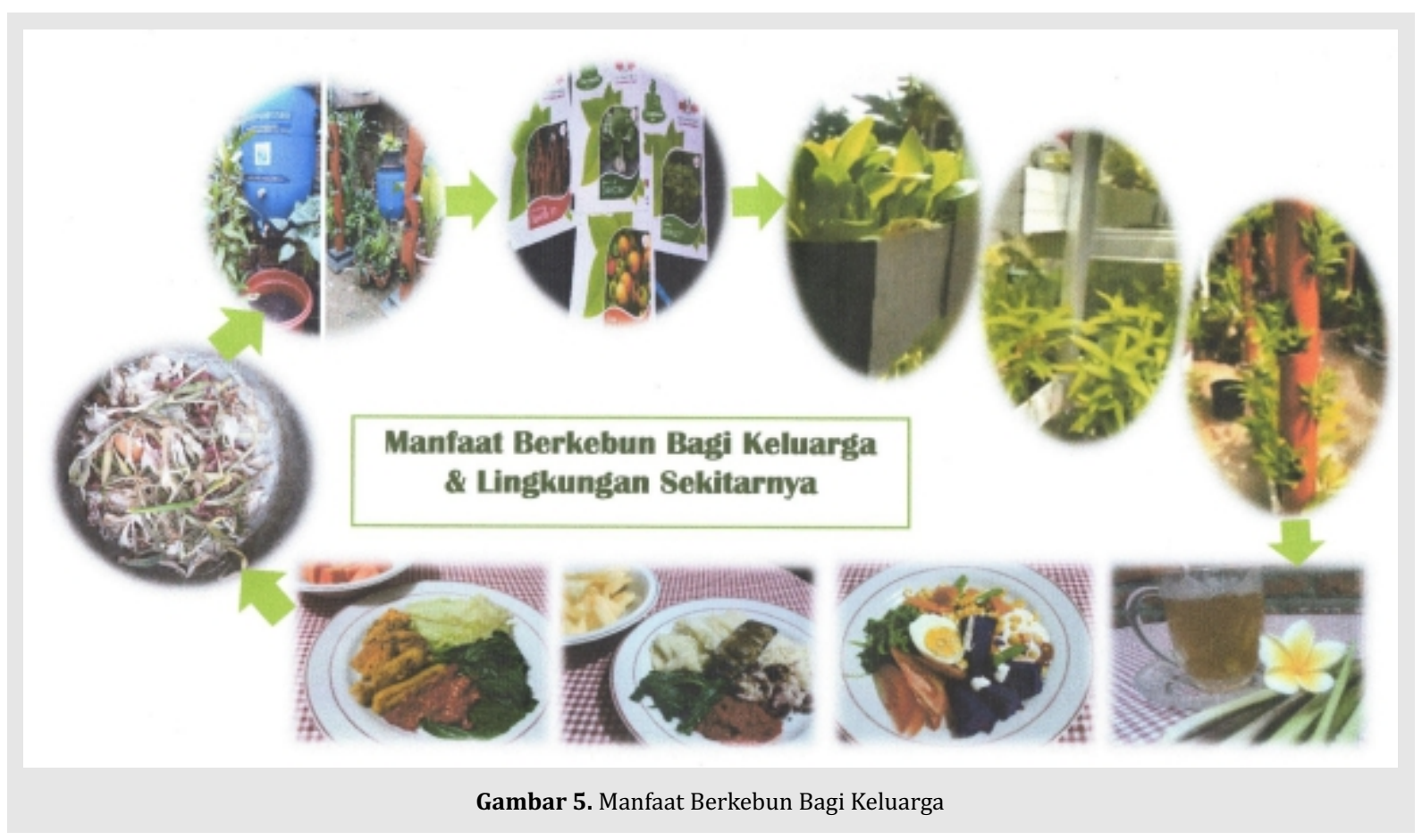


menjembatani antara kebiasaan berkebun dengan perilaku pro-lingkungan. Diawali pilah sampah kemudian sampah dapur atau organik lain dikomposkan menjadi pupuk organik yang selanjutnya digunakan sebagai pupuk. Secara spesifik melalui perilaku berkebun mendorong masyarakat melakukan perilaku pro-lingkungan. Rekayasa sosial berkebun sebagai mekanisme edukasi pro-enviromental behavior kepada warga serta sebagai sarana kompetisi oleh rukun tetangga/rukun warga. Di samping itu berfungsi meningkatkan penerapan ipteks bagi masyarakat meskipun sederhana. Pengetahuan \& kepedulian masyarakat akan meningkat sehingga memperbaiki tata nilai dalam kehidupan bermasyarakat. Secara general rekayasa sosial ini dapat menginspirasi masyarakat berkebun atau menjadi media komunikasi bagi sesama penggiat berkebun.

Sebagai rekomendasi untuk penerapan secara lebih luas perlu didasari oleh komitmen kuat dari kader serta proses evaluasi sehingga proses perbaikan akan dilakukan sebelum musim tanam berikutnya. Kerjasama dengan ahli gizi dapat dilakukan untuk memberikan informasi manfaat sayuran bagi keluarga. Jika sekiranya mitra sangat antusias dan memiliki komitmen kuat dalam berkebun maka dapat direalisasikan melalui kemitraan dengan komunitas hidroponik. Dasar pemahaman tersebut sangat penting supaya luaran yang dibuatkan untuk mitra tidak terbengkalai setelah project berakhir.

\section{Ucapan Terima Kasih}

Terima kasih kepada Kemenristek Dikti dan DPPM Universitas Tarumanagara atas sponsor pendanaan kegiatan di tahun 2018. Tidak lupa terima kasih kami haturkan kepada Ketua Pengerak PKK dan Kader Dasawisma RT 02/02 Kalurahan Beji Timur Depok atas jalinan kerjasama selama kegiatan pengabdian masyarakat.

\section{DAFTAR PUSTAKA}

Blankenberg, A. Kathrin. and Alhusen. H. (2018). On the determinations of pro-environmental behavior - a guide for further investigation, Discussion Papers, Center for European Governance and Economic Development Research, No.350. May. ISSN 1439-2305.

Bamberg, S and Rees. J. (2015). Environmental attitudes and behavior: measurement, Behavioral Sciences, 2nd edition, vol. 7, Oxford: Elsevier, 699-705.

Eisler, A. D., Eisler, H and Yoshida. M. (2003). Perception of human ecology: cross-cultural and gender comparisons",Journal of Environmental Psychology, 23(1), 89-101.

Erhabor, N. I. and Oviabon, C. (2018). Relationship between family functioning and environmental attitude on the environmental behavior of students in a Federal University in Edo State, Nigeria, European Journal of Sustainable Development Research, 2(3)., 28, 1-5.

Gifford, R and Nilsson, A. (2014) Personal and social factor that influence pro environmental concern and behavior: a review., International Journal of Psychology, 46 (3),141-157.

Hoffman, R. and R, Muttarak. (....). Explaining the link education and green behavior in the Philippines: The role of knowledge and Climate Change Perception.

Keiser, F., and Wilson, M (2014). Goal-directed conservation behavior: the spesific composition of a generation performance. Personality and Individual Differences, 26 (2), 1531-1544. DOI: 10.1016/j.paid.2003.06.003.

Kollmuss, A., and Agyeman, J. (2002). Mind the gap: why do people act environmentally and what are the barriesrs to pro-environmental behavior?. Environmental Education Research, 8 (3). 239-260. DOI: $10.1080 / 13504620220145401$. 
Lee, H., Korisu, K., and Hanaki. K. (2013). Influential Factors on Pro-Environmental Behavior-A Case Study in Tokyo and Seoul", Low Carbon Economy, 104-116.

Longhi. S. (2013). Individual Pro-Environmental Behavior in the Household Context, Technical Report, ISER Working Paper Series.

Markle, G (2013). Pro-environment: daes it matter how it's measured? development and validation of the pro-environmental behavior scale (PEBS). Human Ecology. 41 (8), 905-914. DOI 10.1007/s10745013-9614-8.

Palupi, T dan Sawitri D.R. (2017). Hubungan antara sikap dengan perilaku pro-lingkungan di tinjau dari perpektif theory of planned behavior. Proceding Biology Ecudation center. Oktober., 214-217.

Pemberdayaan dan Kesejahteraan Keluarga. (2016). Hasil Rakernas VIII PKK Tahun 2015, Diperbanyak oleh Badan Pemberdayaan dan Kesejahteraan Keluarga.

Sustainable Development Goals, UNDP

Zelezny, L.C., Chua, P.P., and Aldrich. C. (2003). Elaborating on Gender Differences in Environmentalism", Journal of Social Issues, 56 (3), 443-457. 